\title{
NON-CARCINOGENIC RISK ASSESSMENT OF GROUNDWATER IN SOUTHERN PART OF SALEM DISTRICT IN TAMILNADU, INDIA
}

\author{
P. BALAMURUGAN ${ }^{a^{*}}$, P.S. KUMAR ${ }^{b}$, K. SHANKAR $^{c}$, R.NAGAVINOTHINI $^{d}$ AND K.VIJAYASURYA ${ }^{e}$ \\ ${ }^{a}$ Department of Civil Engineering, M.Kumarasamy College of Engineering, Karur, India. \\ ${ }^{b}$ Department of Civil Engineering, University College of Engineering, Ariyalur, India. \\ ${ }^{c}$ Department of Applied Geology, School of Applied Natural Science, Adama Science and Technology University, Ethiopia. \\ ${ }^{d}$ Department of Structures for Engineering and Architecture, University of Naples Federico II, Naples, Italy. \\ ${ }^{e}$ Senior GIS Analyst, Paragon Dynamics Info Systems, Chennai, India.
}

\begin{abstract}
The main objective of this study was to evaluate the groundwater quality for domestic, agriculture use and to describe fluoride contamination in groundwater and their impacts on human health. 67 groundwater samples were collected and analyzed for major ions. Water Quality Index (WQI), Piper diagram and Gibbs diagrams were calculated to measure the suitability of groundwater for drinking purpose. The hazards index value was calculated to estimate the noncarcinogenic risk to adult (male, female) and children suggested by the United States Environmental Protection Agency (USEPA). The irrigation indices were calculated to evaluate the quality of water for irrigation purpose. Statistical methods such as principal component and hierarchical cluster analysis were used to analyses the inter-relationship of data. Hydrochemistry of the samples shows, the major ions in the order of $\mathrm{Ca}^{2+}>\mathrm{Mg}^{2+}>\mathrm{Na}^{+}$and $\mathrm{Cl}^{-}>\mathrm{SO} 4-$ in the study area. WQI value of groundwater, $74.62 \%$ of sample locations are good and $25.38 \%$ of sample locations need primary treatment for drinking purpose. The results of the hazards index show that $65.67 \%$ of the sample locations exceeds the tolerable limit for non-carcinogenic risk (greater than one) for children higher than the risk level for Male and female. Statistical report of PCA and $\mathrm{HCA}$ reveals that $\mathrm{Ca}-\mathrm{Na}-\mathrm{HCO}_{3}-\mathrm{F}$ has positive loading and TDS-EC has negative loading. The study results show that rock-water interaction and anthropogenic activities are the major factors that influence the quality of groundwater. The continuous intake of excess concentration fluoride causes bone diseases and teeth problems.
\end{abstract}

Keywords: Groundwater Quality, Health risk assessment, Fluoride contamination, Water quality index, Irrigation indices, PCA and HCA

\section{INTRODUCTION}

Groundwater is one of the most important sources for domestic and agricultural usage in both rural and urban areas of India. However, it is only a regional resource in many parts of the country. In the recent years, the continuous increase in population, economic development and climate changes adversely distress the nature of water (Zhang et al.,2019a, Radfard et al., 2019, Pinto et al., 2019, Yadav et al., 2019). In a worst scenario, the combination of above factors may lead to non-availability of surface water in many parts of the country (Adimalla et al.,2019a, Francisco et al., 2019, Wongsasuluk et,al 2014, Siirila et al., 2012). Insufficient rainfall in many arid and semi-arid regions being one of the major environmental issue had also resulted in the drastic reduction of surface water along with an increased extraction of groundwater to satisfy the water demand for domestic and agricultural uses especially in agriculture-based countries like India (Shahid et al., 2019, Qasemi et al., 2019, Tabassum et al., 2019, Shankar et al., 2010).

In addition, groundwater is also being polluted with toxic substances due to the increased demand for luxurious environmental setup and anthropogenic activities. The restoration of groundwater quality is also a very tedious process (Ghaderpoori et al., 2019, Ravindra et al., 2019, Shankar et al.,2011a), Thus, there is a need for frequent monitoring of ground water quality and its standards to preserve the water resources for utilization. Verification of water quality will also ensure the reduction in water-borne diseases and development of remedial action for water contamination in the earlier stages (Honarbakhsh et al., 2019, Nair et al., 2019, Motevalli et al., 2019, Zhang et al., 2019b, Shankar et al.,2011b). Hence, it is mandatory to add the improvement of fresh water sources together with conservation through effective monitoring as a basic component in the water plan of any developed or developing nation. The evaluation of human health risk related with high fluoride concentration of groundwater in Salem district Tamilnadu, India, and observed that intake of elevated fluoride contaminated water is the significant reason for increasing human health issues (Adimalla et al., 2019c, Deshpande et al., 2019, Shankar et al.,2011c)

Narsimha et al.,2018 investigated the spatial and monsoon variation of fluoride contamination in groundwater in Southern part of India and stated that continuous consumption of high fluoride water is the main explanation behind collapse of human health (Ahada et al., 2017). Excess concentration of fluoride in groundwater is the principle issue that influences the human health in southern part of Tamilnadu India. Totally 21 states were recorded to be high risk of fluorosis and around 6.5 million children were affected due to intake of excess concentration of fluoride.

Various techniques that are commonly used to assess the groundwater quality are Water Quality Index (WQI), Piper diagram, Gibbs plot for drinking purpose and Sodium Absorption Ratio (SAR), Wilcox diagram, US Salinity Laboratory (USSL) diagram, kelly ratio, permeability index, percentage sodium, magnesium hazards for irrigation purpose (Chitsazan et al., 2019, He et al., 2019, Adimalla et al., 2019b). In addition to the above, multivariate statistical techniques such as principal component analysis and hierarchical cluster analysis methods are also used to evaluate the water quality by categorizing the similarity of chemical compounds and degree of contamination in water (Rotiroti et al., 2019, Stefania et al., 2019, Merz et al., 2019, Masoud et al., 2018, Ferchichi et al., 2018, Ibrahim et al., 2019, Shankar et al.,2011d)

The significant objective of the current study is to measure the chemical characteristics of groundwater in Yercadu Taluk, Salem, India to predict its suitability for drinking and agricultural purposes. The specific objectives of the study include the evaluation of the hydro-chemical characteristics of groundwater for drinking purpose, calculation of WQI and irrigation indices to ensure the water quality for drinking and agricultural purpose respectively. The results of the present study will help in deciding the remedial action for contamination and in enhancing the supply of wholesome water to the public in a study area.

\section{MATERIALS AND METHODOLOGY}

\section{Study area}

Yercadu is a hilly region in Salem District, Tamil Nadu, India (Fig.1) and situated in the Shevaroys series of slopes in the Eastern Ghats. The study area located at an elevation of 1,515 meters (4,970 feet) above mean sea level (MSL), and the most noteworthy location in yercadu is servarayan sanctuary, at $1,623 \mathrm{~m}$ 
$(5,326 \mathrm{ft})$. The total surface area of the yercaud is $382.67 \mathrm{~km} 2$, it includes reserve forest. A climate condition is categories as tropical. The normal temperature in Yercaud is $21.1^{\circ} \mathrm{C}$. The mean precipitation in selected location is $1512 \mathrm{~mm}$ and low precipitation was recorded in January, with an average of $17 \mathrm{~mm}$. In October, the precipitation achieves its top, with a mean of $260 \mathrm{~mm}$. between the summer and winter seasons, the difference in rainfall is observed as $243 \mathrm{~mm}$.

\section{Geology}

The occurrence of Charnockite, for the most part in structural hills in the investigation area. The hard ground rocks are the pre-granulite migmatite combined with charnockite occurs on a basement of tonalite-trondhjemite stone, granodiorite, gneiss. Under the charnockite-konderite group we have supercluster of rocks having a place with layered ultramafic complex, metavolcanics and meta silt. The hydro chemistry of most surface and groundwater is the result of interaction between rain water and rock near the earth surface. Major interaction takes place in the soil zone. The soils are normally wealthy in aluminium and iron and it contains less calcium carbonate. The general equation. 1 for weathering in study area is

\section{Rock + infiltrated water $=$ Altered rock + leachate solution}

Figure. 2 shows the geomorphology of the study area. It is observed that a major part of the study area was covered by granite, dolerite, khondalite, charnockites and peninsular gneiss. The interconnection of shevaroy and lateritic bauxite with charnockites, peninsular gneiss, and dolerite rocks.

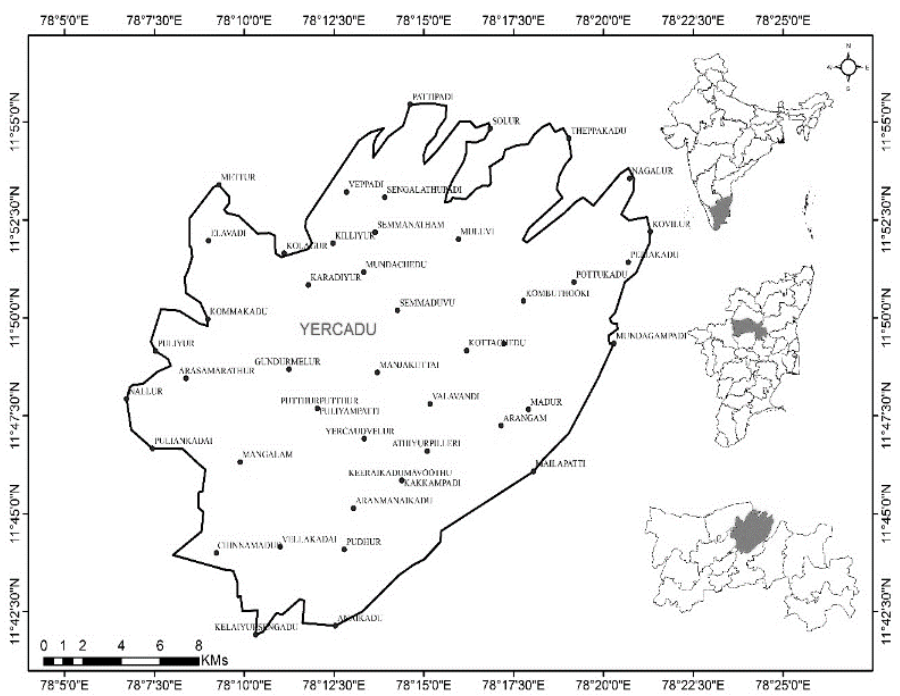

Figure 1. Sample Location in Study area

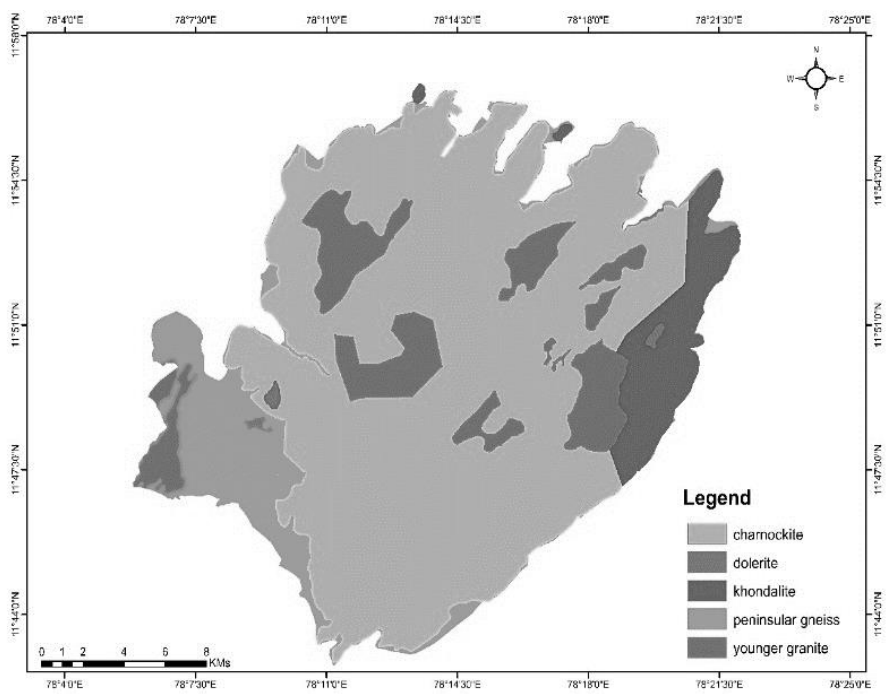

Figure 2. Geology formation of study area

\section{Sampling}

A sampling of groundwater for this study was carried out in July and august in 2017. Groundwater samples were collected from existing bore wells in the study area. Samples were taken after 10-20 min of pumping each hand and bore well to get constant $\mathrm{pH}$ and electrical conductivity values. All samples were collected in prewashed polyethylene 1-L bottles and dried before collection. The samples were maintained at $4^{\circ} \mathrm{C}$ on-site and kept in dark place until analysis.

\section{Analysis methods and accuracy}

Twelve basic groundwater quality parameters including $\mathrm{pH}$, electrical conductivity, total hardness, total dissolved solids, calcium, magnesium, bicarbonate, carbonate, sodium, nitrate, chloride, sulfate were analyzed using standard procedure recommended by American Public Health Association (APHA, 1999). During the sampling, concentration of hydrogen ions $(\mathrm{pH})$, salinity and total dissolved solids values were calculated using portable water quality analyzer (Elico PE 138). A major cations and anions were measured in the laboratory by titration method. An ionic balance error (E) equation is used to get an accuracy of analytical results between the concentration of total cation and anion stated in milliequivalent per liter (meq/L) of all respective sample (Eqn.2).

$$
\mathrm{E}=\frac{\sum \text { Cation }-\sum \text { Anions }}{\sum \text { Cation }-\sum \text { Anions }} \times 100
$$

The value of $\mathrm{E}$ was should not exceed the acceptable limit of $\pm 10 \%$.

\section{Piper trilinear diagram}

A piper trilinear plot is a method of picturing the chemistry of a rock, soil, or water sample. The piper trilinear plot is utilized to conclude hydro-geochemical facies. Hydro chemical facies help to realize the chemical reaction occurring between the minerals inside the lithological structure of the locations. The hydro chemical facies are utilized to clarify the compound creation of water in various hydrologic frameworks. To understand the chemical characteristics of groundwater, most of the scientists have utilized the idea of hydro chemical facies. The hydro chemical facies are a component of flow patterns and lithology.

\section{Gibbs diagram}

Gibbs (1972) has suggested a graphical representation of action for change in water quality and; there are three main mechanisms, which rule the hydrochemistry of waters. These are as follows: (1) evaporation dominance, (2) weathering dominance, and (3) precipitation dominance that control the chemistry composition of waters.

\section{Gibbs Anion Plot equation:}

Gibbs anion $=\frac{\mathrm{Cl}}{\mathrm{Cl}+\mathrm{HCO}}$

Gibbs Cation Plot equation:

Gibbs cation $=\frac{\mathrm{Na}+\mathrm{K}}{\mathrm{Na}+\mathrm{K}+\mathrm{Ca}}$

\section{Water quality index}

Water quality Index (WQI) is a successful tool for assessing the all-purpose nature of groundwater, which is essentially decreases the immense quantity of groundwater quality information into a values and meanwhile it effectively describes the information about the water nature (Adimalla et al., 2018, Li et al. 2018, Zakir et al., 2018, Rao et al., 2019, Nemčić-Jurec et al., 2019, Abbasnia et al., 2019, Lentz et al., 2018, Bhuiyan et al., 2010). WQI commonly used to estimate the fitness of the groundwater for domestic purposes in different countries around the world. In the present study, each parameter has been allotted different weights (Wi) as per its importance and effects in nature of water for domestic uses. The most extreme load of "five" has been allocated for nitrate in water quality assessment and the base load of 'two' has been given for calcium and magnesium. The allotted weight, relative weight and standard values for each chemical parameter were computed and tabulated (Table.1). WQI values were classified into six classes are excellent, good, moderate, poor, very poor and unsuitable for domestic uses (Table.2). In any case, the following eqn. (5) - (8) are associated with WQI estimation: 


$$
\begin{aligned}
& W i=\frac{w i}{\sum_{i}^{n} w i} \\
& Q i=\frac{V i-V o}{S i-V o} \times 100 \\
& S I i=W i \times Q i \\
& W Q I=\sum_{i=1}^{n} S I i
\end{aligned}
$$

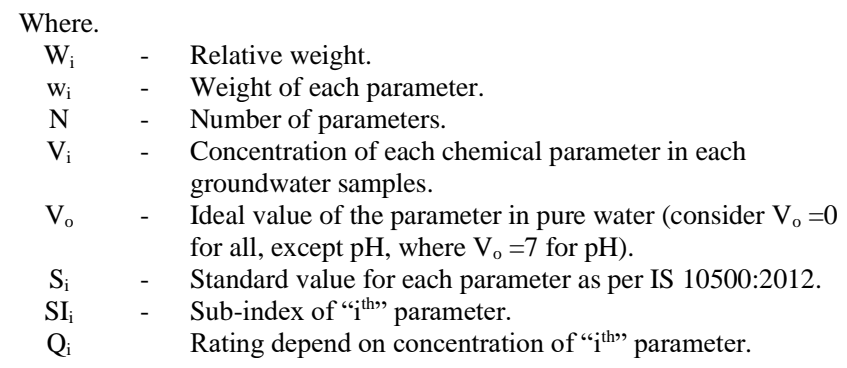

Table 1. Standard value, Weight and relative weight of each parameters.

\begin{tabular}{|c|c|c|c|}
\hline Parameter & $\begin{array}{c}\text { Standard Value } \\
\text { (IS 10500:2012) }\end{array}$ & $\begin{array}{c}\text { Weight } \\
\text { (wi) }\end{array}$ & $\begin{array}{c}\text { Relative Weight } \\
\text { (Wi) }\end{array}$ \\
\hline pH & $6.5-8.5$ & 4 & 0.12903 \\
\hline Calcium & $75-200$ & 2 & 0.06452 \\
\hline Magnesium & $30-100$ & 2 & 0.06452 \\
\hline Bicarbonate & $240-730$ & 3 & 0.09677 \\
\hline Chloride & $250-1000$ & 3 & 0.09677 \\
\hline Total Dissolved solids & $500-2000$ & 4 & 0.12903 \\
\hline Fluoride & $1-1.5$ & 4 & 0.12903 \\
\hline Nitrate & $45-100$ & 5 & 0.16129 \\
\hline Sulphate & $200-400$ & 4 & 0.12903 \\
\hline
\end{tabular}

\section{Risk assessment model}

Human health risk evaluation is huge and essential to defend the nature of groundwater assessment. Additionally, potential human healthiness threat evaluation is the procedure to evaluate the probable adverse dangerous human welfare impacts on babies, children and adults (Karunanidhi et al.,2019, Narsimha et al.,2018). However, expressed that several elements that reason human health risks through washing are moderately questionable. The main objective of this study is to evaluate the health impact of drinking water on study area peoples. (Shahid et al., 2019, Qasemi et al., 2019, Tabassum et al., 2019).

$$
\begin{aligned}
& E=\frac{C P W \times I R \times E D \times E F}{A B W \times A E T} \\
& H Q=\frac{E}{R f D}
\end{aligned}
$$

Where.

E - Chronic daily intake, it is expressed in $\mathrm{mg}$ per $\mathrm{kg} / \mathrm{day}$.

CPW - Concentration of specific pollutant in groundwater in mg per day.

IR - Rate of human ingestion in Litres per day.

ED - Duration of exposure and expressed in years.

EF - Frequency of exposure and expressed in no. of days per years.

ABW - Average body weight in Kilogram.

AET - Average time in days.

HQ - Non-carcinogenic for hazard quotient.

RfD - Reference dose of fluoride and expressed in $\mathrm{mg} / \mathrm{kg} / \mathrm{day}$

\section{Irrigation water quality indices}

There is an expanding need to intermittently check the nature of water used for agriculture purposes. It expands the harvest yield and helps in the development of prevalent yields, which require good quality of water. With the developing condition, depends on rainwater for agriculture is dangerous. Subsequently, the nature of water for irrigation purpose is focused in this study. Significant irrigation water quality parameters incorporate several specific properties of water important in connection to the yield and nature of harvests. The irrigation indices are Sodium Adsorption Ratio (SAR), Residual Sodium Carbonate (RSC), Permeability Index (PI), Magnesium Hazard (MH) and Percentage Sodium $(\% \mathrm{Na})$. The result of the indices states that suitability of groundwater quality for agriculture uses.

Sodium Absorption Ratio equation:

$S A R=\frac{N a}{\sqrt{(C a+M g) / 2}}$

Residual Sodium Carbonate equation:

$R S C=\frac{\mathrm{HCO} 3+\mathrm{CO} 3}{\mathrm{Ca}+\mathrm{Mg}}$

Permeability Index equation:

$P I=\frac{\sqrt{\mathrm{HCO} 3}+\mathrm{Na}}{\sqrt{(\mathrm{Na}+\mathrm{Mg}+\mathrm{Ca}}}$

Magnesium Hazards equation:

$M H=\frac{\mathrm{Mg} \times 100}{C a+M g}$

Percentage Sodium equation:

$\% N a=\frac{(\mathrm{Na}+\mathrm{K}) \times 100}{C a+M g+N a+K}$

\section{Spatial analysis}

The groundwater quality parameters measured in the study area was represented through maps in ArcGIS Software (10.1). This software is used to interpolate the sampling points with characteristics of groundwater throughout the study area. In this study, Inverse Distance Weighting (IDW) interpolation techniques was used to attribute the value and calculating surrounding point within the defined boundary area. A level of contamination was highlighted by following 6-D stretch model in GIS (Khan et al.,2019, Nath et al.,2018, Patra et al.,2018, Amos et al.,2018, An et al.,2016, Collin et al.,2003).

\section{Statistical Analysis}

The groundwater quality parameters and their inter-relationship were explored by the multivariate statistics such as mean, maximum, minimum, standard deviation and correlation analysis (Golkarian et al.,2018, Wu et al.,2019, Sahoo et al.,2019, Everest et al.,2019). In this study, PCA and HCA methods were utilized to categorize the primary factors that stimulus the groundwater quality in the investigated region. The major parameters calcium, magnesium sodium, chloride, sulphate, total dissolved solids and total hardness were selected for principal component analysis. The factors having the minimum eigen value of one were extracted. All multivariate statistical analysis was completed using SPSS version. 20 tool.

\section{RESULT AND DISCUSSION}

\section{Quality of water for drinking purpose}

\section{Hydrochemistry Classification:}

Piper trilinear diagrams was plotted using diagramme application and the result shows that, hydrochemistry structure of the water samples collected in the study area (Fig.3). A trilinear plot show that $\mathrm{Ca}^{2+}, \mathrm{Mg}^{+}$and $\mathrm{Na}^{+}$of cation, $\mathrm{HCO}^{3-}, \mathrm{Cl}^{-}$ and $\mathrm{SO}_{4}{ }^{2-}$ of anion parameters are predominant in the study area. The diagram exposes that the major water type is $\mathrm{Ca}-\mathrm{Mg}-\mathrm{SO}_{4}(37.31 \%)$ and $\mathrm{Na}-\mathrm{Cl}-\mathrm{SO}_{4}$ $(37.31 \%)$. The less dominants in the groundwater area are: $\mathrm{Ca}-\mathrm{Mg}-\mathrm{HCO}_{3}$ $(20.89 \%)$ and $\mathrm{SO}_{4}, \mathrm{HCO}_{3}(4.47 \%)$. When groundwaters type Ca-Mg-SO $\mathrm{S}_{4}$ and $\mathrm{Na}-$ 
$\mathrm{Cl}-\mathrm{SO}_{4}$ reveals that, rock water interaction and nature of aquifer influencing the groundwater quality in the study area.

\section{Hydrochemistry Mechanism}

In a study area, anion and cation Gibbs plots reveals, most of the samples fell into rock- water interaction and some of the samples fell in the evaporation field (Fig.4). It shows that, rock-water interaction influences the quality of groundwater in the study area. The concentration of $\mathrm{Na} / \mathrm{Na}+\mathrm{Ca}$ ratio will lead by the action of leaching of salts in rocks. The different nature of aquifers in the study area inhabit the conversion region between evaporation and rock-water interaction dominance field.

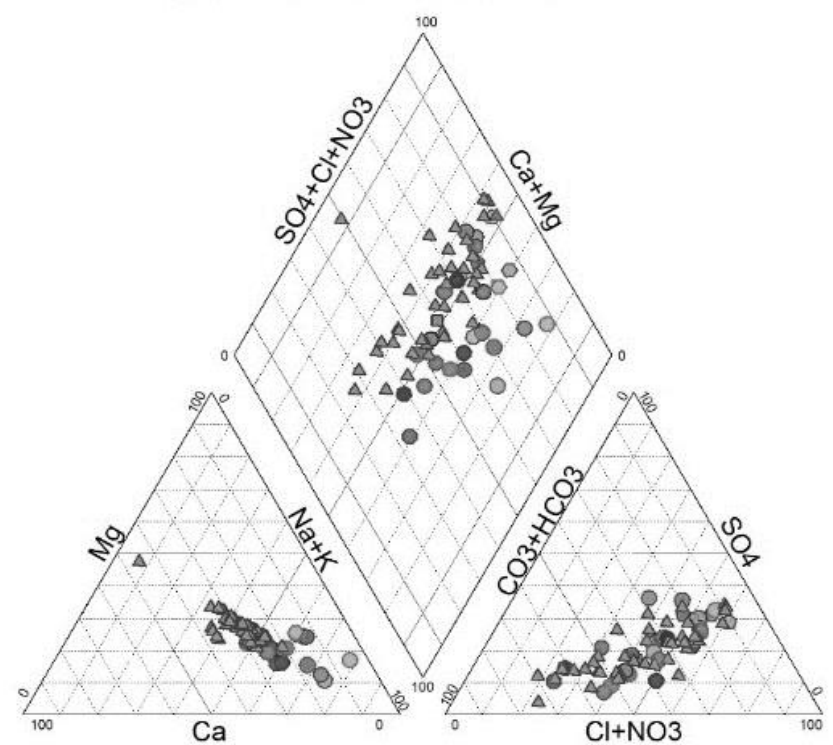

Figure 3. Piper Trilinear classification of groundwater.

a)

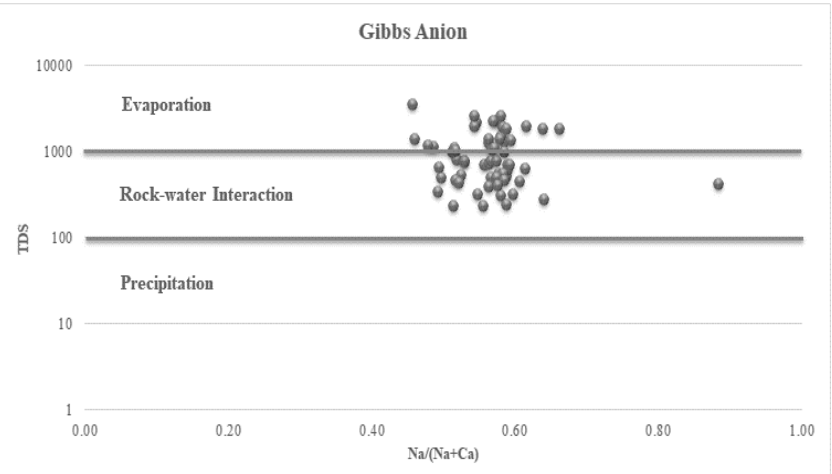

b)

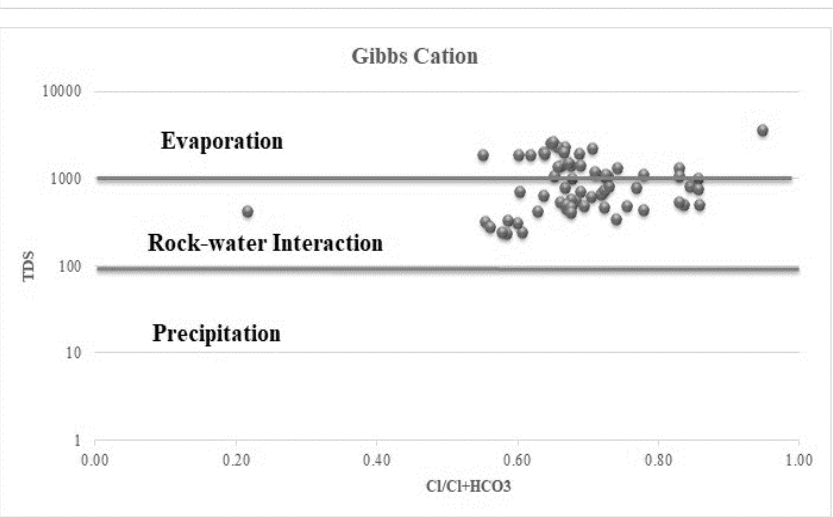

Figure 4. Hydrochemistry mechanism of groundwater a) Gibbs anion and b) Gibbs Cation

\section{Hydro geochemistry of groundwater}

Hydrochemical parameters of the water are taken as major measures in classifying the nature of the groundwater. The statistical analysis of the groundwater in the study area are presented in Table (4)

The concentration of hydrogen ions $(\mathrm{pH})$ of the drinking water in the study area was range from 7.14 to 8.45 . The level of $\mathrm{pH}$ concentrations is doesn't exceed the permissible limits (6.5-8.5) recommended by WHO and IS10500. A higher value of $\mathrm{pH}$ recorded in the Gundur village (Fig.5 a). The presence of calcareous nature of aquifers in the study area is a major reason for the elevated level of $\mathrm{pH}$.

A Total Dissolved Solids (TDS) in groundwater were range from 231 to 3479 $\mathrm{mg} / \mathrm{L}$. In the study area, $23.42 \mathrm{Sq} . \mathrm{Km}$ is permissible, $355.31 \mathrm{Sq} . \mathrm{Km}$ is acceptable and $7.74 \mathrm{Sq} . \mathrm{Km}$ of the area is unfit for drinking purpose (Fig.5 b) The greater value of TDS was recorded in veppadi, kolangur and arangam villages. The concentration of total alkalinity (TA) and total hardness (TH) in the drinking water was range from 37 to $901 \mathrm{mg} / \mathrm{L}$ and 105 to $1105 \mathrm{mg} / \mathrm{L}$ respectively.

In the study area, the range of total alkalinity is $170.27 \mathrm{Sq} . \mathrm{Km}$ is permissible, $212.57 \mathrm{Sq} . \mathrm{Km}$ is acceptable and $3.62 \mathrm{Sq} . \mathrm{Km}$ of the area is unsuitable (Fig. 6a) and the range of total hardness are $34.2 \mathrm{Sq} . \mathrm{Km}$ is permissible, $317.23 \mathrm{Sq} . \mathrm{Km}$ is acceptable and $35.03 \mathrm{Sq} . \mathrm{Km}$ is unsuitable for drinking purpose (Fig.6b). The greater TA and TH values are noted in the kolangur and arangam villages. This might due to deposition of municipal solids waste leachate and rock water interaction.

The concentration of calcium $(\mathrm{Ca} 2+)$ and magnesium $(\mathrm{Mg} 2+)$ in the groundwater samples was range from 18.65 to $2251.85 \mathrm{mg} / \mathrm{L}$ and 8.18 to 146.68 $\mathrm{mg} / \mathrm{L}$ respectively. The total area covered by calcium ions is $218.09 \mathrm{Sq} . \mathrm{Km}$ is permissible, $165.44 \mathrm{Sq} . \mathrm{Km}$ is acceptable and $2.93 \mathrm{Sq} . \mathrm{Km}$ is unsuitable for drinking purpose (Fig 7a). Calcium ions with the combination of carbonate, bicarbonate, chloride, and sulfate are naturally present in the groundwater. A greater value of calcium ions was recorded in madur and arangam villages.

Some anthropogenic activities like an excessive amount of fertilizer, pesticides used for crop yield and rock water interaction are the major cause of higher concentration of calcium ions. In a study area, the concentration of magnesium ions are $81.06 \mathrm{Sq} . \mathrm{Km}$ is permissible, $295.64 \mathrm{Sq} . \mathrm{Km}$ is acceptable and 9.76 Sq.Km is unsuitable for drinking purpose (Fig. $7 \mathrm{~b}$ ).

The higher concentration of magnesium ions was recorded in arangam and assambur villages. Magensium is the amplest component in the earth crust. It is widely present in younger granite and dolerite rocks in the study area. The excess concentration of magnesium in the groundwater samples causes different health problems.

The concentration of Chloride (Cl-) and sulphate (SO42- ) in the water samples was range from 37 to $581 \mathrm{mg} / \mathrm{L}$ and 17 to $510 \mathrm{mg} / \mathrm{L}$ respectively. The concentration of chloride was $279.12 \mathrm{Sq} . \mathrm{Km}$ is permissible and $107.34 \mathrm{Sq} . \mathrm{Km}$ is unfit for drinking purpose in the study area (Fig.8a). A dissolution of mineral in groundwater such as khondalite, Charnockite, and peninsular gneiss are the major reason for higher concentration chloride ion. The concentration of sulphate ions was $275.11 \mathrm{Sq} . \mathrm{Km}$ is permissible, 109.08 Sq.Km is acceptable and 2.27 Sq.Km are unsuitable for drinking purpose (Fig.8b). This might be due to the disposal of industrial waste and anthropogenic activities

The concentration of nitrate and fluoride in the drinking water range from 6 to $85 \mathrm{mg} / \mathrm{L}$ and $0.2-1.9 \mathrm{mg} / \mathrm{L}$ respectively in the study area. The concentration of fluoride was $384.52 \mathrm{Sq} . \mathrm{Km}$ is permissible and $1.94 \mathrm{Sq} . \mathrm{Km}$ is unfit for drinking purpose (Fig.9a). The higher concentration of fluoride ions might be younger granite, dolerite, khondalite, disposal of municipal waste and anthropogenic activities. The level of nitrate in groundwater was $378.09 \mathrm{Sq} . \mathrm{Km}$ is permissible and $8.37 \mathrm{Sq} . \mathrm{Km}$ is unsuitable for drinking purpose (Fig.9b). The greater value of nitrate was recorded in veppadi and kolangur villages. The hydrochemistry studies stated that, excess level of contamination in water. A major two factors, rock-water interaction and anthropogenic activities such as the application of pesticides and fertilizers regularly used in the agricultural lands are the major reason for degradation of the groundwater. 
a)

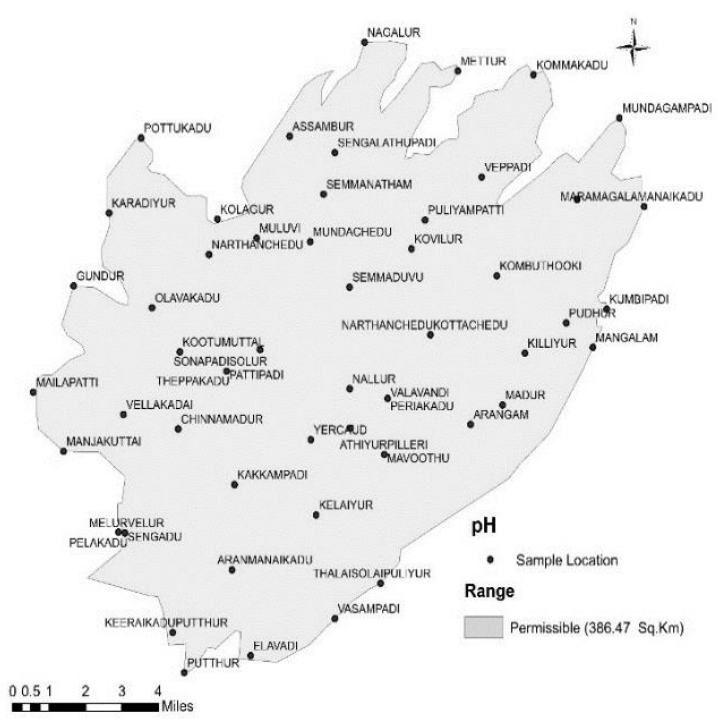

Figure 5. Spatial variation of concentration of a) $\mathrm{pH}$ b) TDS in study area.

a)

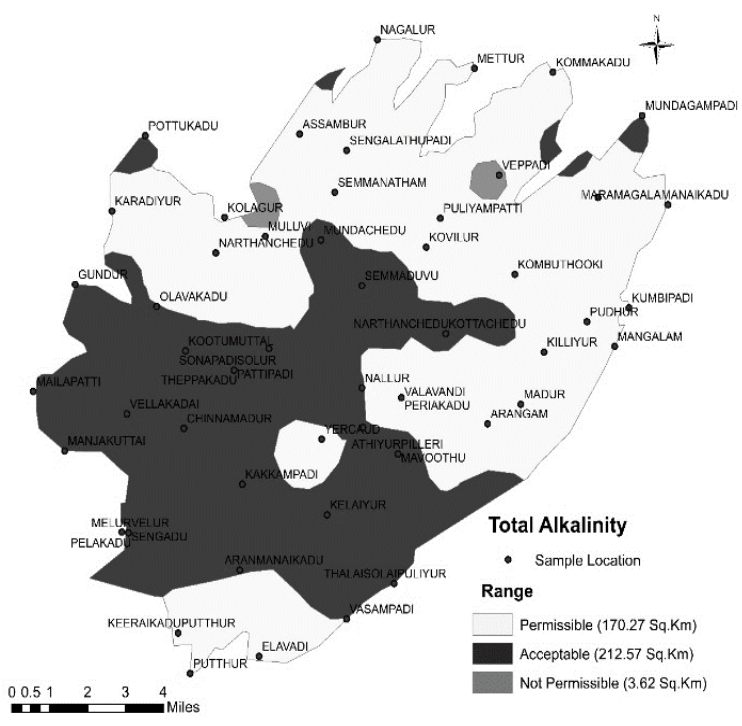

Figure 6. Spatial variation of concentration of a) TA b) TA in study area.

a)

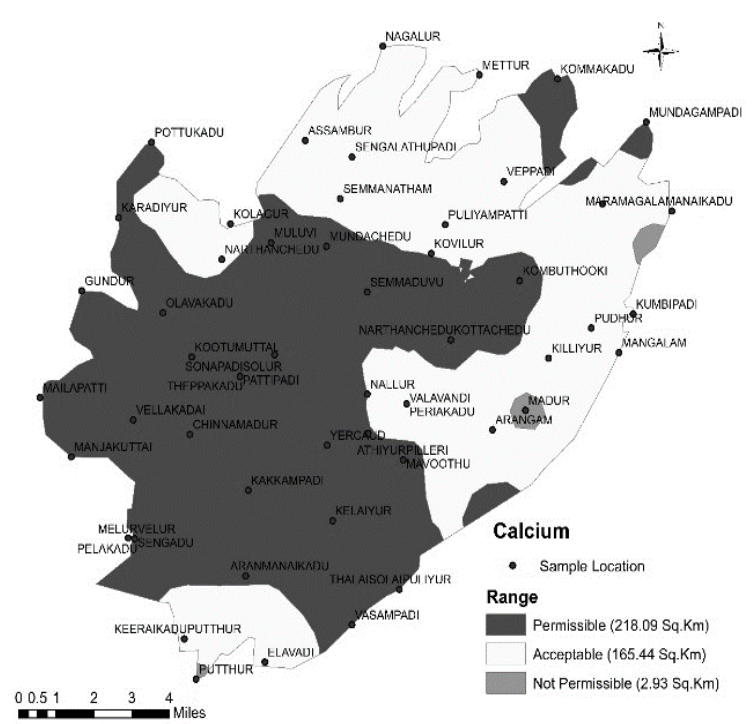

b)

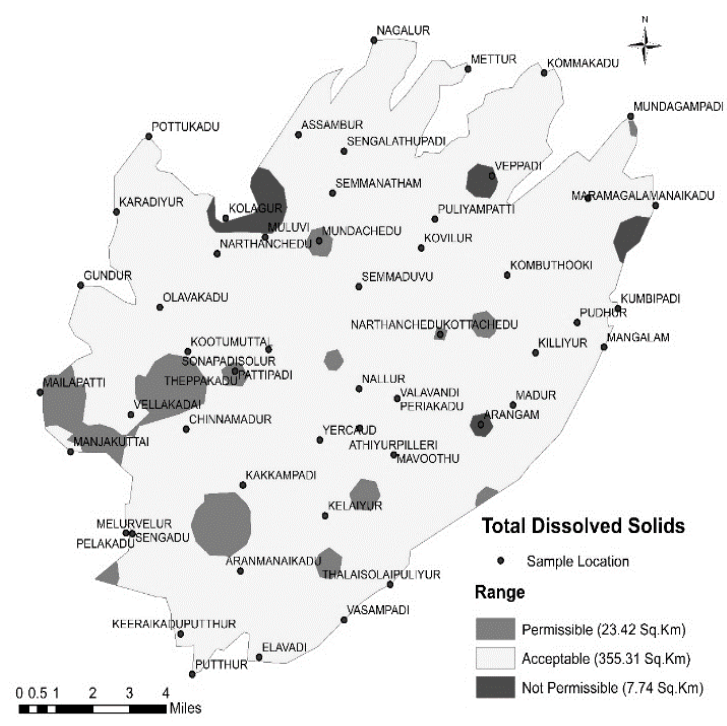

b)

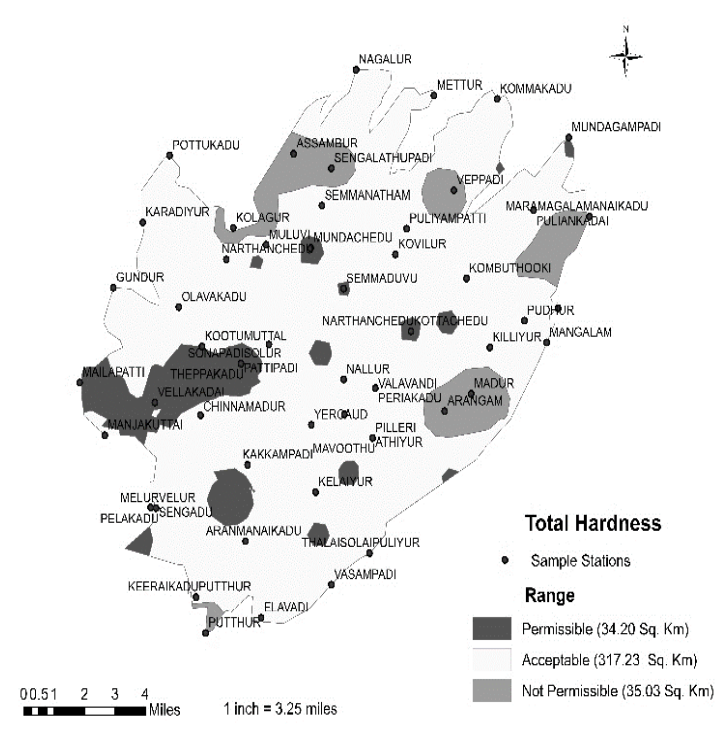

b)

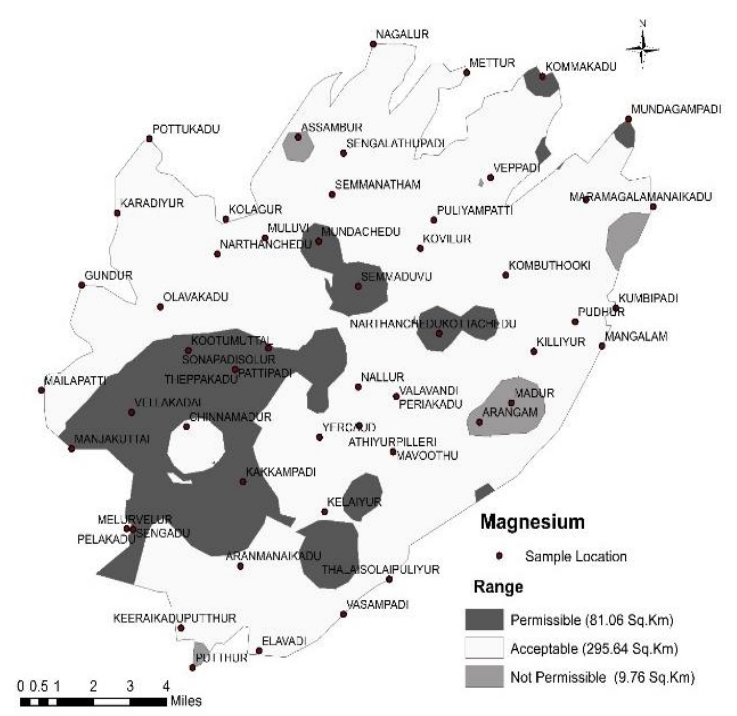

Figure 7. Spatial variation of concentration of a) $\mathrm{Ca}$ b) $\mathrm{Mg}$ in study area. 
a)

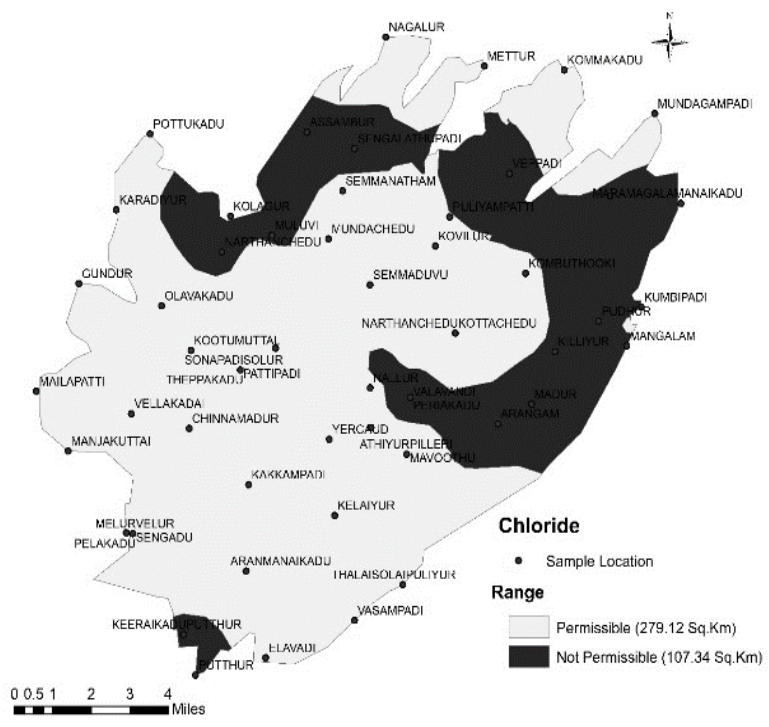

Figure 8. Spatial variation of concentration of a) $\mathrm{Cl}-$ b) $\mathrm{SO} 4$ in study area.

a)

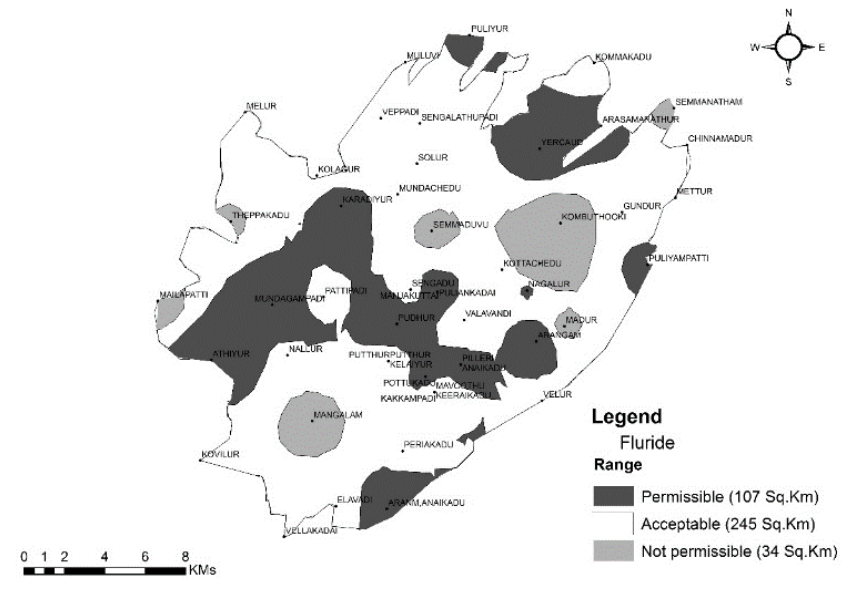

Figure 9. Spatial variation of concentration of a) F- b) NO3- in study area.

\section{Water quality index and Health risk assessment}

In Table 2 represent the five different water classes based on WQI value, namely excellent (WQI range between 0 to 25), good (WQI range between 26 to 50), Moderate (WQI range between 51 to 75), Poor (WQI range between 76 to 100 ), Very poor (WQI range greater than 100). In a study area, out of 64 sample locations, $38.8 \%$ of the samples (26 locations) are excellent, $35.82 \%$ of the samples (24 locations) are good, $19.40 \%$ of the samples (13 locations) are moderate and $5.98 \%$ of the samples (4 locations) are poor for drinking purpose. Excess concentration of $\mathrm{Ca}, \mathrm{Mg}$, TDS, $\mathrm{K}, \mathrm{F}$ and $\mathrm{TH}$ are a major reason for the high value of WQI in the study area. A highly affected 4 sample stations were originated in the southern part of the study area and these villages are affected due to municipal waste disposal and anthropogenic activities.

In a study area, as per WQI, $25.38 \%$ of the samples needed treatment for drinking purpose. After a detailed investigation in a study area observed that there is no surface water source and most of the peoples depend on groundwater for their daily activities and it is essential to monitor the health issue assessment due to elevated concentration of fluoride in some specified locations. The model was introduced by USEPA to assess the health risks due to the higher concentration of parameters in groundwater. The estimated values of noncarcinogenic for hazard quotient (HQ) for adult and children through different water pathways in the study area are shown in Table.3.

The HQ value of fluoride was computed, and it is greater than 1 . The HQ in Adult $_{\text {male }}$ ranged from 0.077 to 1.795 with an average of $0.780,0.091$ to 2.121 b)

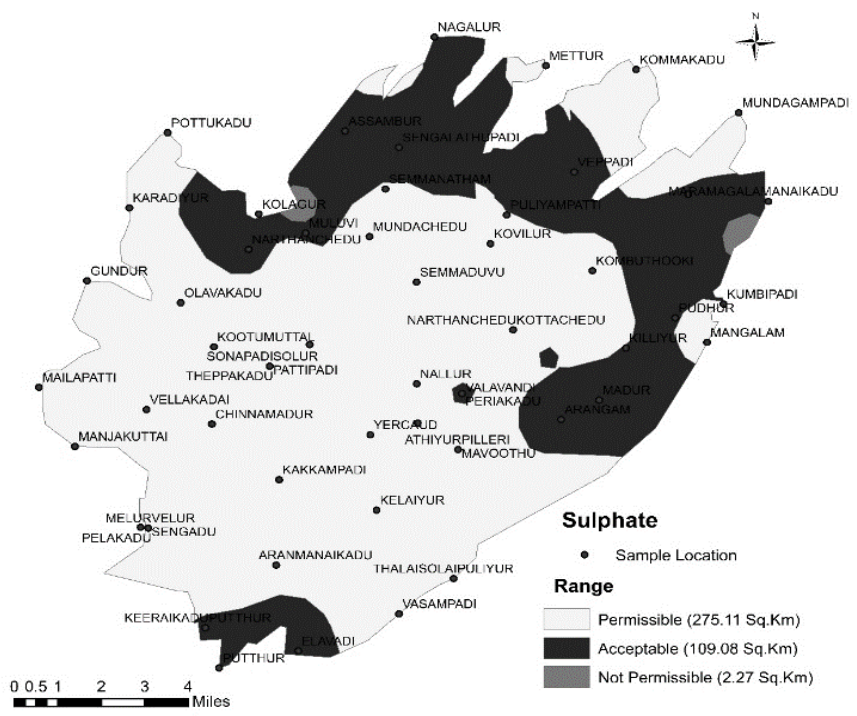

b)

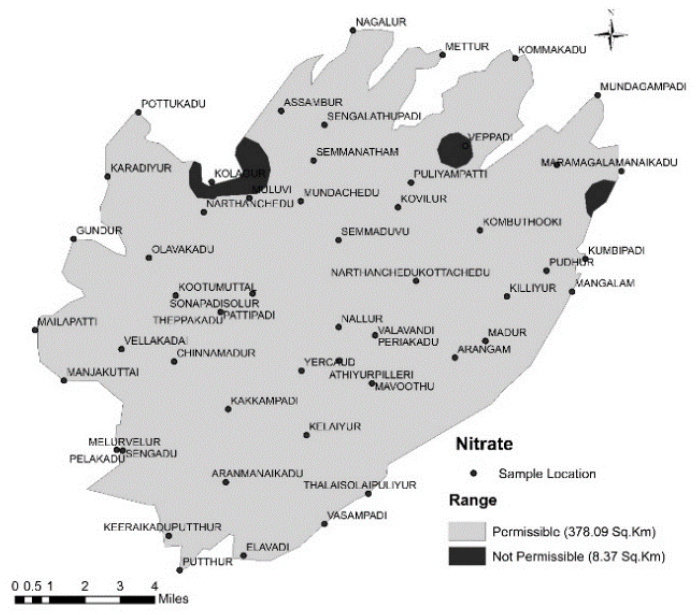

with a mean of 0.922 for Adult female $_{\text {fand }}$ an 104 to 2.427 with an average of 1.055 for children. Over $65.67 \%$ of the sample locations exceeds the acceptable limit for non-carcinogenic risk (greater than 1) for children, $17.91 \%$ and $46.26 \%$ of the samples locations were higher than the risk level for Male and female respectively (Table.3). The hazards index level of health problems on the order of Children > Adult females $>$ Adult $_{\text {males }}$ was observed in the study area (Fig.10). A high concentration of fluoride in the groundwater causes the dental and skeletal fluorosis problem to the children. Granite and gneissic rocks are highly occupied the higher portion of the study area which supplies a huge amount of fluoride ion to the groundwater during the action of rock-water interaction

Table 2. Water quality classification - WQI value.

\begin{tabular}{|c|c|c|c|l|}
\hline $\begin{array}{c}\text { WQI } \\
\text { Value }\end{array}$ & $\begin{array}{c}\text { Water } \\
\text { Quality }\end{array}$ & $\begin{array}{c}\text { No. of } \\
\text { samples }\end{array}$ & $\begin{array}{c}\text { \% of } \\
\text { samples }\end{array}$ & \multicolumn{1}{|c|}{ Purpose of uses } \\
\hline $0-25$ & Excellent & 26 & 38.80 & Drinking and irrigation \\
\hline $26-50$ & Good & 24 & 35.82 & Drinking and irrigation \\
\hline $51-75$ & Moderate & 13 & 19.40 & $\begin{array}{l}\text { Irrigation and treatment } \\
\text { needed for before } \\
\text { drinking }\end{array}$ \\
\hline $76-100$ & Poor & 4 & 5.98 & $\begin{array}{l}\text { Need attention for } \\
\text { irrigation }\end{array}$ \\
\hline$>100$ & $\begin{array}{c}\text { Very } \\
\text { poor }\end{array}$ & - & - & Unfit for all uses \\
\hline
\end{tabular}


Table 3. Noncarcinogenic risk and water quality index value of groundwater.

\begin{tabular}{|c|c|c|c|c|}
\hline \multirow{2}{*}{ Humans } & Hazards value & Health risk & No. of samples & \% of samples \\
\hline \multirow{2}{*}{ Male } & $<1$ & Low & 55 & 82.09 \\
\cline { 2 - 5 } & $>1$ & High & 12 & 17.91 \\
\hline \multirow{2}{*}{ Female } & $<1$ & Low & 36 & 53.73 \\
\cline { 2 - 5 } & $>1$ & High & 31 & 46.26 \\
\hline \multirow{2}{*}{ Children } & $<1$ & Low & 23 & 34.33 \\
\cline { 2 - 5 } & $>1$ & High & 44 & 65.67 \\
\hline
\end{tabular}

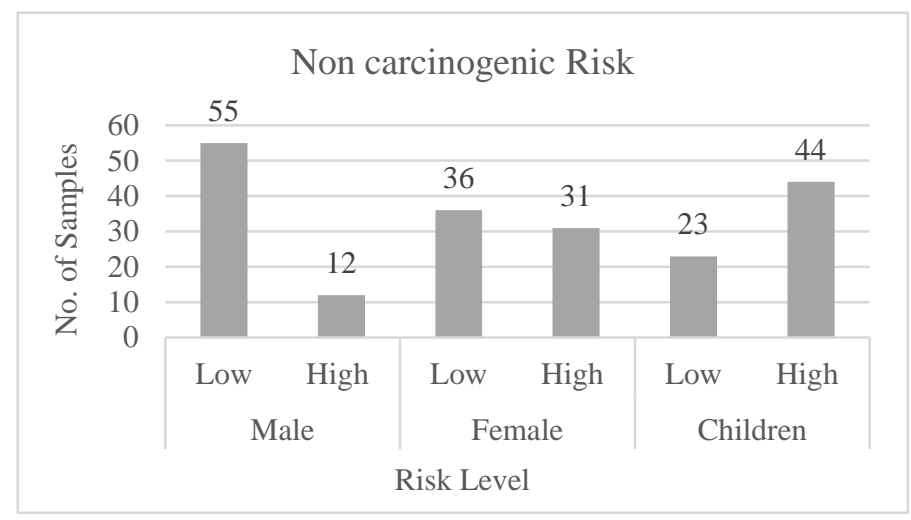

Figure10. Level of noncarcinogenic risk in study area.

\section{Quality of water for irrigation purpose}

\section{Sodium Absorption Ratio}

In United States Salinity Laboratory (USSL) diagram reveals that relationship between sodium absorption ratio and salinity hazards concentration in the groundwater. SAR values range from 0.07 to 8.47, with mean of 3.48 (Table.5), A concentration of salinity hazards (EC) range between 334 to $4974 \mu \mathrm{S} / \mathrm{cm}$ with mean value of $1427.49 \mu \mathrm{S} / \mathrm{cm}$ (Table.4) and both parameters are used in the USSL classification.

Figure 11 reveals that $78 \%$ of samples fell in C3S1 category (high salinity and low sodium hazards), it indicates it may affect crop growth and yield, nutritional disorders and cause osmotic effects to the plant due to high salinity. About $11 \%$ of samples fall in C2S1 category (Medium salinity and low sodium hazards), indicating good for crop yield and all agriculture works. Only $9 \%$ of the samples fell in the C4S2 category (Very high salinity and medium sodium hazards) and 2 $\%$ of the samples fell in C4S3 category (Very high salinity and high sodium hazards).

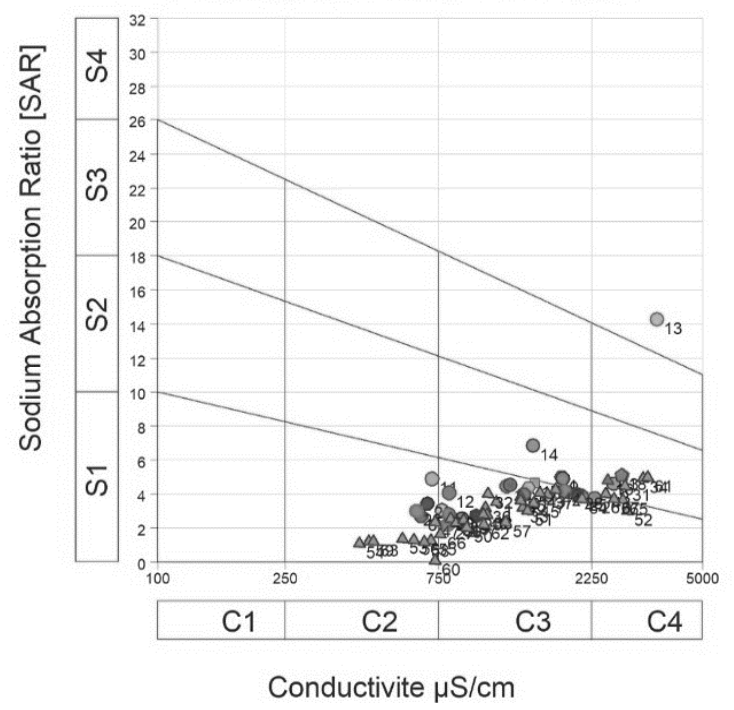

Figure 11. USSL Classification of groundwater in study area.

\section{Residual Sodium Carbonate}

Carbonate and Bicarbonate are the major parameters that influence the quality of groundwater for agriculture uses. The combination of nature earth materials like calcium and magnesium with carbonate and bicarbonate highly affect the nature of water. When the sum of carbonates and bicarbonates are in surplus of sum of $\mathrm{Ca}^{2+}$ and $\mathrm{Mg}^{2+}$. The effects of carbonate and bicarbonate in groundwater has evaluated by calculating the RSC value (Eq.12). The greater value of RSC in water results for higher concentration of adsorption of sodium ions. If the value of RSC is greater than $2.5 \mathrm{meq} / \mathrm{L}$ indicate quality of water is unsuitable for agriculture, whereas the value is less than $1.25 \mathrm{meq} / \mathrm{L}$ indicate sources of water is fit for agriculture and the value range between 1.26 to $2.5 \mathrm{meq} / \mathrm{L}$ was doubtful for irrigation work (Table.5). In a study area, $88 \%$ of the sample (59 locations) was good, $6 \%$ of the samples (4 locations) was doubtful and $6 \%$ of the samples (4 locations) was unfit for irrigation purpose.

\section{Magnesium hazard (MH)}

An excess concentration of magnesium ions in water has rearrange the properties of soil through changing it into alkaline earth nature, it reflects in low crop yield. Magnesium hazards value has been proposed by Szabolcs and Darab (1964) is to identify the groundwater water sample is suitable for agriculture works (Eq.14). The value of Magnesium hazards exceeds 50, the sources of water is unsuitable and the value is less than 50, that the sources of water is suitable for irrigation works (Table.5). Based on MH value, $57 \%$ of the samples (38 locations) was suitable and $43 \%$ of the samples (29 locations) was unsuitable for irrigation purpose.

\section{Permeability index (PI)}

Permeability is an important physical property of soils that transmit water flow through in it. The permeability of soil is commonly affected by the long-term application of excess concentration of sodium, calcium, magnesium and bicarbonate water. Higher concentration of sodium leads to the affect the physical properties of soil by reducing the permeability and it changes the nature of earth material. The permeability index has been computed by using Eq.11. and it is expressed in meq/L. PI Value is greater than 75 (Class I), it is safe, the value range between $25-75 \mathrm{meq} / \mathrm{L}$ (Class II), it shows that marginally safe and less than $25 \mathrm{meq} / \mathrm{L}$ denotes, the water is unsafe for irrigation purpose (Table.5). In a Study area, $31 \%$ of the samples (21 locations) are safe and $69 \%$ of the samples (46 locations) are marginally safe for irrigation purpose.

\section{Percentage Sodium $(\% \mathrm{Na})$}

Wilcox (1955) has used to classify groundwater based on concentration of $\% \mathrm{Na}$ and Electrical Conductivity and its divided in to five classes. The percentage sodium exceeds $60 \%$, the water is not acceptable for agriculture work. In a study area, the classification of water classes is excellent (1 location), Good (9 locations), Permissible (49 locations) and Doubtful (8 locations). Majority of the samples falls under the Good to permissible category (Figure.12). It shows that, the quality of groundwater was started to deteriorate its nature due to disposal of municipal waste from urban area.

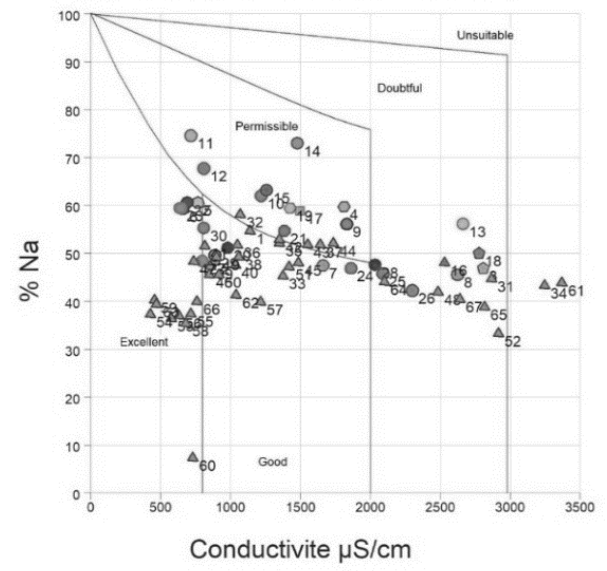

Figure 12. Wilcox Classification of groundwater in study area. 
Table 4. Statistical representation of groundwater quality.

\begin{tabular}{|c|c|c|c|c|c|c|c|}
\hline Parameter & Units & Min & Max & Average & SD & $\begin{array}{c}\text { WHO } \\
(\mathbf{2 0 1 3})\end{array}$ & $\begin{array}{c}\text { BIS } \\
\text { (IS:10500) }\end{array}$ \\
\hline $\mathrm{pH}$ & - & 7.14 & 8.45 & 7.86 & 0.38 & $6.5-8.5$ & $6.5-8.5$ \\
\hline $\mathrm{EC}$ & $\mu \mathrm{S} / \mathrm{cm}$ & 334 & 4974 & 1427.49 & 984.05 & 1400 & - \\
\hline $\mathrm{TDS}$ & $\mathrm{mg} / \mathrm{L}$ & 231 & 3479 & 996.48 & 688.85 & $500-1500$ & 500 \\
\hline $\mathrm{TA}$ & $\mathrm{mg} / \mathrm{L}$ & 37 & 901 & 235.48 & 168.31 & 300 & 150 \\
\hline $\mathrm{TH}$ & $\mathrm{mg} / \mathrm{L}$ & 105 & 1105 & 364.21 & 254.39 & $100-500$ & 200 \\
\hline $\mathrm{Ca}$ & $\mathrm{mg} / \mathrm{L}$ & 18.65 & 251.85 & 81.97 & 62.80 & $75-200$ & 75 \\
\hline $\mathrm{Mg}$ & $\mathrm{mg} / \mathrm{L}$ & 8.18 & 146.68 & 48.59 & 37.12 & $50-150$ & 30 \\
\hline $\mathrm{Na}$ & $\mathrm{mg} / \mathrm{L}$ & 3.27 & 685.47 & 161.86 & 116.38 & 200 & - \\
\hline $\mathrm{K}$ & $\mathrm{mg} / \mathrm{L}$ & 6.93 & 69.63 & 26.81 & 16.77 & 12 & - \\
\hline $\mathrm{NO}_{3}$ & $\mathrm{mg} / \mathrm{L}$ & 6 & 85 & 19.57 & 17.78 & 50 & 45 \\
\hline $\mathrm{Cl}$ & $\mathrm{mg} / \mathrm{L}$ & 37.00 & 581 & 216.24 & 143.87 & $200-600$ & 250 \\
\hline $\mathrm{F}$ & $\mathrm{mg} / \mathrm{L}$ & 0.2 & 1.9 & 0.37 & 0.37 & 1.2 & 1 \\
\hline $\mathrm{SO}_{4}$ & $\mathrm{mg} / \mathrm{L}$ & 17.00 & 510 & 156.61 & 128.48 & $200-400$ & 200 \\
\hline
\end{tabular}

Min-Minimum, Max-Maximum and SD- Standard Deviation.

Table 5. Classification of groundwater for agriculture uses.

\begin{tabular}{|c|c|c|c|c|}
\hline S.NO & RANGE & CLASS & NO OF SAMPLES & \% OF SAMPLES \\
\hline \multicolumn{5}{|c|}{ Sodium Absorption Ratio } \\
\hline 1 & $0-10$ & Excellent & 67 & 100 \\
\hline 2 & $10-18$ & Good & 0 & 0 \\
\hline 3 & $18-26$ & Doubtful & 0 & 0 \\
\hline 4 & $>26$ & Unfit & 0 & 0 \\
\hline \multicolumn{5}{|c|}{ Residual Sodium Carbonate } \\
\hline 1 & $<1.25$ & Good & 59 & 88 \\
\hline 2 & $1.25-2.5$ & Doubtful & 4 & 6 \\
\hline 3 & $>2.5$ & Unfit & 4 & 6 \\
\hline \multicolumn{5}{|c|}{ Permeability Index } \\
\hline 1 & $>75$ & Class-I & 21 & 31 \\
\hline 2 & $25-75$ & Class-II & 46 & 69 \\
\hline 3 & $<25$ & Class-III & 0 & 0 \\
\hline \multicolumn{7}{|c|}{ Magnesium Hazards } \\
\hline 1 & $<50$ & Suitable & 38 \\
\hline 2 & $>50$ & Unsuitable & 29 \\
\hline \multicolumn{7}{|c|}{ Percentage Sodium } \\
\hline 1 & $<20$ & Excellent & 14 & 21 \\
\hline 2 & $20-40$ & Good & 21 & 43 \\
\hline 3 & $40-60$ & Permissible & 18 \\
\hline 4 & $60-80$ & Doubtful & 14 \\
\hline 5 & $>80$ & Unfit & 0 & 21 \\
\hline
\end{tabular}

\section{Statistical analysis of groundwater}

\section{Principal Component Analysis (PCA)}

In PCA, fourteen quality parameters have been given as input to discriminating the various process that influences the nature of groundwater quality. The range of variable was uniquely depending on the eigenvalue of less than 1. Varimax rotation method was followed to calculate the maximum value of the sum of the variance of factor coefficient, which clearly described the possible sources of contamination in the study area. The higher values in PCA shows that sample is influenced by the parameters that continuously loaded on a source, meanwhile, the negative values indicate that quality of water is generally unaffected by those parameters.
In a study area, water quality parameters were grouped into two major components in PCs, reveals $86.81 \%$ of the total variance in the data set (Table 6). The parameters are sodium and bicarbonate, calcium and fluoride have the high positive values in factor component 1 and 2 respectively (Fig.13a). To compute the number of components to be taken to understand the primary chemical structure of groundwater by using a scree plot. Component 1 has more than $85 \%$ of the variance has been explained the structure of groundwater (Fig.13.b, c).

The HCA was a widely used method to identify the grouping of chemical variables in groundwater chemistry. This method generally used to group variable into cluster-based on resemblances in such a way that individual cluster describes a specific action in a groundwater system. Figure.14 reveals that, level of grouping of a parameter in groundwater. Parameters fitted into the same cluster are probable to have originated from a similar source. In this study, Rmode cluster analysis was used to grouping in the groundwater parameters, which reported the 2-main cluster. Cluster 1 consists of $\mathrm{Na}, \mathrm{HCO} 3, \mathrm{SO} 4, \mathrm{Cl}, \mathrm{TA}$, $\mathrm{pH}, \mathrm{F}, \mathrm{K}, \mathrm{NO}, \mathrm{Mg}, \mathrm{Ca}, \mathrm{TH}$ and this is like factors components 1 in PCA method. Cluster 2 consists of TDS and EC. From the statistical report of PCA and HCA reveals that Na-HCO3- SO4- Cl- TA- pH- F- K- NO3- Mg- Ca- TH and TDSEC. which are largely resulting from natural (Rock-water interaction) and anthropogenic sources. Highly noted anthropogenic activities in the study area are municipal waste disposal and industrial effluent in the recharging point of the aquifer.

Table 6. Principal component analysis of groundwater with variance and eigen values.

\begin{tabular}{|l|c|c|}
\hline \multirow{2}{*}{ pH } & \multicolumn{2}{|c|}{ COmponent } \\
\cline { 2 - 3 } EC & 0.029 & PCA2 \\
\hline TDS & 0.095 & -0.472 \\
\hline TA & 0.095 & -0.044 \\
\hline TH & 0.094 & -0.044 \\
\hline Ca & 0.077 & -0.106 \\
\hline Mg & 0.053 & 0.123 \\
\hline Na & 0.068 & $\mathbf{0 . 2 7 2}$ \\
\hline K & $\mathbf{0 . 1 0 3}$ & 0.187 \\
\hline NO3 & 0.085 & -0.159 \\
\hline Cl & 0.092 & 0.000 \\
\hline F & 0.088 & -0.025 \\
\hline SO4 & -0.063 & 0.006 \\
\hline HCO3 & 0.090 & $\mathbf{0 . 6 3 8}$ \\
\hline Eigen value & $\mathbf{0 . 1 0 2}$ & 0.004 \\
\hline \% of Variance & $\mathbf{1 0 . 8 5 5}$ & -0.156 \\
\hline Cumulative \% & $\mathbf{7 7 . 5 3 4}$ & $\mathbf{1 . 2 9 9}$ \\
\hline & $\mathbf{7 7 . 5 3 4}$ & $\mathbf{9 . 2 7 8}$ \\
\hline
\end{tabular}

a)

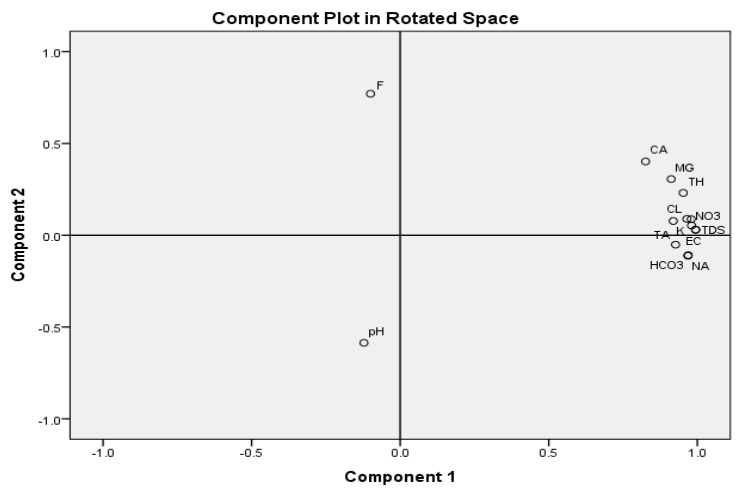


b)

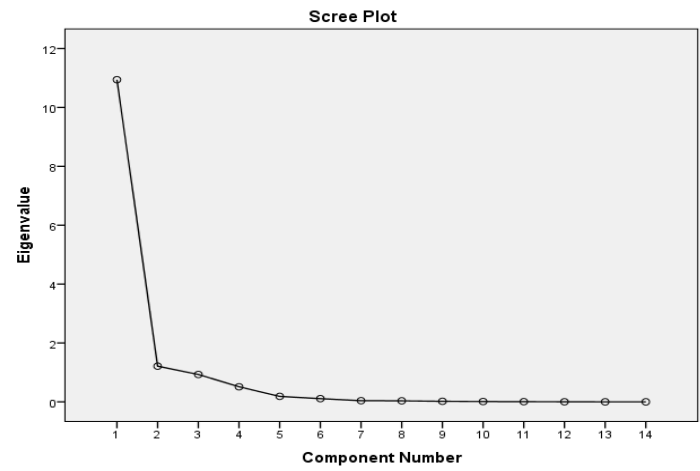

c)

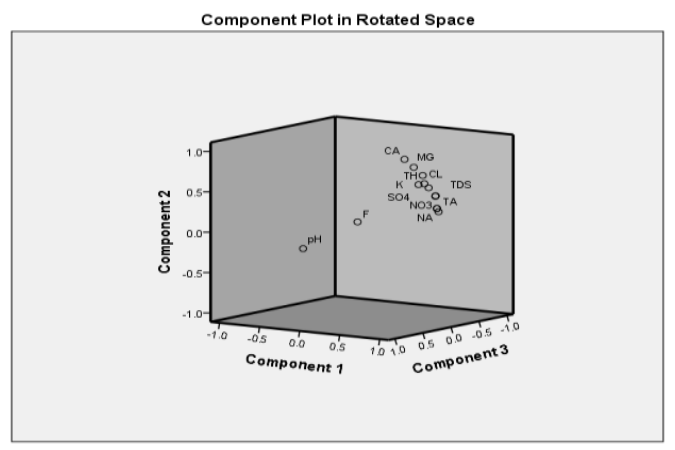

Figure 13. a) Principal Components of analysis b) Scree plot C) Component plot of parameters.

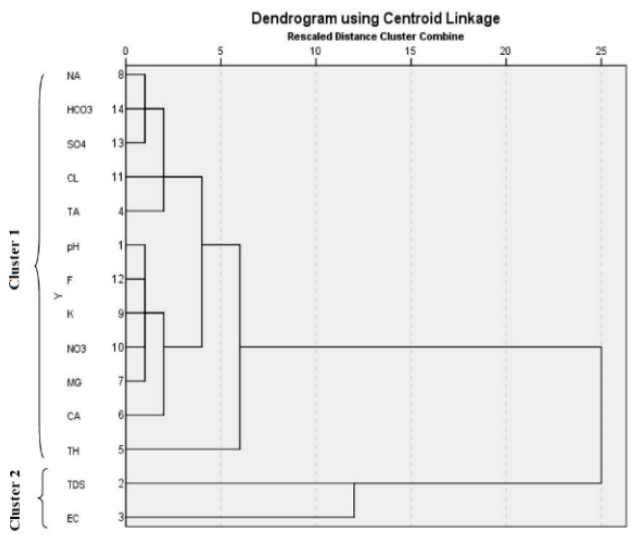

Figure 14. Dendrogram classification of groundwater in study area

\section{CONCLUSIONS}

Groundwater is the major sources for domestic and agricultural uses in Yercad taluk, Tamilnadu, India which is largely occupied by khondalite, charnockite, peninsular gneiss, younger granite, and dolerite. In general, the rural area peoples in the study area depends on groundwater for both drinking and irrigation purpose. The concentration of each parameter was compared to WHO (2008) and IS10500:2012 standards to ensure the appropriateness of the groundwater for both purposes, different graphical methods were used to assess the quality of groundwater in a study area. Moreover, the following conclusion is drawn:

1.Piper trilinear diagram reveals that groundwaters were $\mathrm{Ca}-\mathrm{Mg}-\mathrm{SO} 4(37.31 \%)$ and $\mathrm{Na}-\mathrm{Cl}-\mathrm{SO} 4(37.31 \%)$ type. The distribution of major anion and cation in the order of $\mathrm{Ca}^{2+}>\mathrm{Mg}^{2+}>\mathrm{Na}^{+}$and $\mathrm{Cl}^{-}>\mathrm{SO}^{2-}>\mathrm{NO}^{-}>\mathrm{HCO}^{-}$respectively. It reveals that rock water interaction and the nature of aquifer influencing the groundwater quality in the study area.

2. Gibbs diagrams show that $72 \%$ of the groundwater samples fell in rock-water interaction with lithology and $28 \%$ of the samples fall in the evaporation field due to the influence of anthropogenic activities. The different nature of aquifers in the study area inhabit the conversion region between evaporation and rock-water interaction dominance field.
3. A concentration of fluoride ranges from 0.12 to $2.8 \mathrm{mg} / \mathrm{L}$ with a mean of $1.21 \mathrm{mg} / \mathrm{L}$, it is observed that $18 \%$ of the locations are beyond the maximum allowable limits of $1.5 \mathrm{mg} / \mathrm{L}$ and unsuitable for drinking purposes. It might be due to rock-water interaction and anthropogenic activities in the Yercadu region. Irrigation indices suggest that the maximum of the groundwater sample locations in the study area is suitable for agriculture uses.

4. Human health risk assessment results reveal that children are affected at a high level of risk than adults with an excess concentration of fluoride in the study area. The hazard index values for Adult $t_{\text {male }}$ ranged from 0.077 to 1.795 with an average of $0.780,0.091$ to 2.121 with a mean of 0.922 for Adult Female and 0.104 to 2.427 with an average of 1.055 for children. The hazards index level of

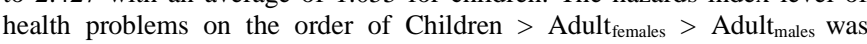
observed in the study area (Fig.10). A high concentration of fluoride in the groundwater causes the dental and skeletal fluorosis problem to the children. Granite and gneissic rocks are highly occupied the higher portion of the study area which supplies a huge amount of fluoride ion to the groundwater during the action of rock-water interaction.

5. Based on the statistical report of PCA and HCA reveals that Na-HCO3- SO4Cl- TA- pH- F- K- NO3- Mg- Ca- TH and TDS-EC. which are largely resulting from natural (Rock-water interaction) and anthropogenic sources. Highly noted anthropogenic activities in the study area are municipal waste disposal and industrial effluent in the recharging point of an aquifer are identified, considering the positive value of the principal component.

6 . The changing of a hydro chemical parameter of groundwater is due to impact of anthropogenic activities and rock-water interaction are identified in the present study and the study recommended that periodical monitoring and improve the management methods of an aquifer, rainwater harvesting, and artificial recharge point are necessary to reduce the water-borne diseases and for sustainable development.

\section{REFERENCE}

1. Abbasnia, A., Yousefi, N., Mahvi, A. H., Nabizadeh, R., Radfard, M., Yousefi, M., \& Alimohammadi, M. (2019). Evaluation of groundwater quality using water quality index and its suitability for assessing water for drinking and irrigation purposes: Case study of Sistan and Baluchistan province (Iran). Human and Ecological Risk Assessment: An International Journal, 25(4), 988-1005.

2. Adimalla, N., Li, P., \& Venkatayogi, S. (2018). Hydrogeochemical evaluation of groundwater quality for drinking and irrigation purposes and integrated interpretation with water quality index studies. Environmental Processes, 5(2), 363-383.

3. Adimalla, N., Li, P., \& Qian, H. (2019a). Evaluation of groundwater contamination for fluoride and nitrate in semi-arid region of Nirmal Province, South India: a special emphasis on human health risk assessment (HHRA). Human and Ecological Risk Assessment: An International Journal, 25(5), 1107-1124.

4. Adimalla, N., \& Qian, H. (2019b). Groundwater quality evaluation using water quality index (WQI) for drinking purposes and human health risk (HHR) assessment in an agricultural region of Nanganur, south India. Ecotoxicology and environmental safety, 176, 153-161.

5. Adimalla, N. (2019c). Groundwater quality for drinking and irrigation purposes and potential health risks assessment: a case study from semi-arid region of South India. Exposure and Health, 11(2), 109-123.

6. Ahada, C. P., \& Suthar, S. (2017). Assessment of human health risk associated with high groundwater fluoride intake in southern districts of Punjab, India. Exposure and Health, 1-9.

7. Amos, C. C., Rahman, A., \& Gathenya, J. M. (2018). Economic analysis of rainwater harvesting systems comparing developing and developed countries: A case study of Australia and Kenya. Journal of cleaner production, 172, 196-207.

8. An, D., Xi, B., Wang, Y., Xu, D., Tang, J., Dong, L., Ren, J. \& Pang, C. (2016). A sustainability assessment methodology for prioritizing the technologies of groundwater contamination remediation. Journal of Cleaner Production, 112, 4647-4656.

9. APHA. 1995. Standard Methods for the Examination of Water and Wastewater. 19th ed. American Public Association, Washington, DC, USA

10. Bhuiyan, M.A.H., Islam, M.A., Dampare, S.B., Parvez, L., Suzuki, S., 2010. Evaluation of hazardous metal pollution in irrigation and drinking water systems in the vicinity of a coal mine area of north western Bangladesh. J. Hazard. Mater. 179, 1065-1077

11. BIS, 2012. Bureau of Indian standards drinking water specifications, BIS 10500:2012. New Delhi, India. 
12. Chitsazan, M., Aghazadeh, N., Mirzaee, Y., \& Golestan, Y. (2019). Hydrochemical characteristics and the impact of anthropogenic activity on groundwater quality in suburban area of Urmia city, Iran. Environment, development and sustainability, 21(1), 331-351.

13. Collin, M. L., \& Melloul, A. J. (2003). Assessing groundwater vulnerability to pollution to promote sustainable urban and rural development. Journal of Cleaner Production, 11(7), 727-736.

14. Deshpande, S. M., \& Aher, R. K. (2019). Suitability of Groundwater Quality for Drinking and Irrigation Purposes in the Dheku River Basin, Maharashtra. Bulletin of Pure \& Applied Sciences-Geology, (1).

15. Everest, T., \& Özcan, H. (2019). Applying multivariate statistics for identification of groundwater resources and qualities in NW Turkey. Environmental monitoring and assessment, 191(2), 47.

16. Francisco, L. F. V., do Amaral Crispim, B., Spósito, J. C. V., Solórzano, J. C. J., Maran, N. H., Kummrow, F., Barufatti, A. (2019). Metals and emerging contaminants in groundwater and human health risk assessment. Environmental Science and Pollution Research, 1-14.

17. Ferchichi, H., Hamouda, M. B., Farhat, B., \& Mammou, A. B. (2018). Assessment of groundwater salinity using GIS and multivariate statistics in a coastal Mediterranean aquifer. International journal of environmental science and technology, 15(11), 2473-2492.

18. Ghaderpoori, M., Paydar, M., Zarei, A., Alidadi, H., Najafpoor, A. A., Gohary, A. H., \& Shams, M. (2019). Health risk assessment of fluoride in water distribution network of Mashhad, Iran. Human and Ecological Risk Assessment: An International Journal, 25(4), 851-862.

19. Gibbs R.J, 1970, Mechanisms controlling world water chemistry. Science 170, 1088-1090.

20. Golkarian, A., Naghibi, S. A., Kalantar, B., \& Pradhan, B. (2018). Groundwater potential mapping using C5. 0, random forest, and multivariate adaptive regression spline models in GIS. Environmental monitoring and assessment, 190(3), 149.

21. He, S., \& Wu, J. (2019). Hydrogeochemical characteristics, groundwater quality, and health risks from hexavalent chromium and nitrate in groundwater of Huanhe Formation in Wuqi county, northwest China. Exposure and Health, 11(2), 125-137.

22. Honarbakhsh, A., Tahmoures, M., Tashayo, B., Mousazadeh, M., Ingram, B., \& Ostovari, Y. (2019). GIS-based assessment of groundwater quality for drinking purpose in northern part of Fars province, Marvdasht. Journal of Water Supply: Research and Technology-Aqua, 68(3), 187-196.

23. Ibrahim, R. G. M., Korany, E. A., Tempel, R. N., \& Gomaa, M. A. (2019). Processes of water-rock interactions and their impacts upon the groundwater composition in Assiut area, Egypt: Applications of hydrogeochemical and multivariate analysis. Journal of African Earth Sciences, 149, 72-83.

24. ICMR (Indian Council of Medical Research). 2009. Nutrient requirements and recommended dietary allowances for Indians. Indians National Institute of Nutrition, Hyderabad, p. 334.

25. Karunanidhi, D., Aravinthasamy, P., Subramani, T., Wu, J., \& Srinivasamoorthy, K. (2019). Potential health risk assessment for fluoride and nitrate contamination in hard rock aquifers of Shanmuganadhi River basin, South India. Human and Ecological Risk Assessment: An International Journal, 1-21.

26. Khan, M. S., Qadir, A., Javed, A., Mahmood, K., Amjad, M. R., \& Shehzad, S. (2019). Assessment of aquifer intrinsic vulnerability using GIS based Drastic model in Sialkot area, Pakistan. International Journal of Economic and Environmental Geology, 73-84.

27. Li, P., He, S., He, X., \& Tian, R. (2018). Seasonal hydrochemical characterization and groundwater quality delineation based on matter element extension analysis in a paper wastewater irrigation area, northwest China. Exposure and Health, 10(4), 241-258.

28. Lentz, R. D., Carter, D. L., \& Haye, S. V. (2018). Changes in groundwater quality and agriculture in forty years on the Twin Falls irrigation tract in southern Idaho. Journal of soil and water conservation, 73(2), 107-119.

29. Masoud, A. A., El-Horiny, M. M., Atwia, M. G., Gemail, K. S., \& Koike, K. (2018). Assessment of groundwater and soil quality degradation using multivariate and geostatistical analyses, Dakhla Oasis, Egypt. Journal of African Earth Sciences, 142, 64-81.

30. Merz, C., \& Lischeid, G. (2019). Multivariate analysis to assess the impact of irrigation on groundwater quality. Environmental Earth Sciences, 78(9), 274

31. Motevalli, A., Pourghasemi, H. R., Hashemi, H., \& Gholami, V. (2019). Assessing the Vulnerability of Groundwater to Salinization Using GISBased Data-Mining Techniques in a Coastal Aquifer. In Spatial Modeling in GIS and $R$ for Earth and Environmental Sciences (pp. 547-571).

32. Nath, B. K., Chaliha, C., Bhuyan, B., Kalita, E., Baruah, D. C., \& Bhagabati, A. K. (2018). GIS mapping-based impact assessment of groundwater contamination by arsenic and other heavy metal contaminants in the Brahmaputra River valley: A water quality assessment study. Journal of Cleaner Production, 201, 1001-1011.

33. Nair, N. C., Srinivas, Y., Magesh, N. S., \& Kaliraj, S. (2019). Assessment of groundwater potential zones in Chittar basin, Southern India using GIS based AHP technique. Remote Sensing Applications: Society and Environment, 100248

34. Narsimha, A., \& Rajitha, S. (2018). Spatial distribution and seasonal variation in fluoride enrichment in groundwater and its associated human health risk assessment in Telangana State, South India. Human and Ecological Risk Assessment: An International Journal, 24(8), 2119-2132.

35. Nemčić-Jurec, J., Singh, S. K., Jazbec, A., Gautam, S. K., \& Kovač, I (2019). Hydrochemical investigations of groundwater quality for drinking and irrigational purposes: two case studies of Koprivnica-Križevci County (Croatia) and district Allahabad (India). Sustainable Water Resources Management, 5(2), 467-490.

36. Pinto, M. M. C., Ordens, C. M., de Melo, M. T. C., Inácio, M., Almeida, A. Pinto, E., \& da Silva, E. A. F. (2019). An Inter-disciplinary Approach to Evaluate Human Health Risks Due to Long-Term Exposure to Contaminated Groundwater Near a Chemical Complex. Exposure and Health, 1-16.

37. Patra, S., Mishra, P., \& Mahapatra, S. C. (2018). Delineation of groundwater potential zone for sustainable development: A case study from Ganga Alluvial Plain covering Hooghly district of India using remote sensing, geographic information system and analytic hierarchy process. Journal of Cleaner Production, 172, 2485-2502

38. Qasemi, M., Afsharnia, M., Zarei, A., Farhang, M., \& Allahdadi, M. (2019). Non-carcinogenic risk assessment to human health due to intake of fluoride in the groundwater in rural areas of Gonabad and Bajestan, Iran: a case study. Human and Ecological Risk Assessment: An International Journal, 25(5), 1222-1233.

39. Radfard, M., Yunesian, M., Nabizadeh, R., Biglari, H., Nazmara, S., Hadi, M., Mahvi, A. H. (2019). Drinking water quality and arsenic health risk assessment in Sistan and Baluchestan, Southeastern Province, Iran. Human and Ecological Risk Assessment: An International Journal, 25(4), 949-965.

40. Rao, K. N., \& Latha, P. S. (2019). Groundwater quality assessment using water quality index with a special focus on vulnerable tribal region of Eastern Ghats hard rock terrain, Southern India. Arabian Journal of Geosciences, 12(8), 267.

41. Ravindra, K., \& Mor, S. (2019). Distribution and health risk assessment of arsenic and selected heavy metals in Groundwater of Chandigarh, India. Environmental Pollution, 250, 820-830.

42. Rotiroti, M., Zanotti, C., Fumagalli, L., Taviani, S., Stefania, G. A., Patelli, M., Leoni, B. (2019). Multivariate statistical analysis supporting the hydrochemical characterization of groundwater and surface water: a case study in northern Italy. Rend. Online Soc. Geol. Ital, 47, 90-96.

43. Sahoo, P. K., Dall'Agnol, R., Salomão, G. N., Junior, J. D. S. F., da Silva, M. S., Martins, G. C., da Costa, M. F. (2019). Source and background threshold values of potentially toxic elements in soils by multivariate statistics and GIS-based mapping: a high density sampling survey in the Parauapebas basin, Brazilian Amazon. Environmental geochemistry and health, 1-28.

44. Shankar, K., Aravindan, S., Rajendran, S., 2010. GIS based groundwater quality mapping in Paravanar River Sub-Basin, Tamil Nadu, India International Journal of Geomatics and Geosciences, 1(3), 282-296.

45. Shankar, K., Aravindan, S. and Rajendran, S., 2011a. Spatial distribution of groundwater quality in Paravanar river sub basin, Cuddalore district, Tamil Nadu. International Journal of Geomatics and Geosciences, 1(4), 914-931.

46. Shankar, K., Aravindan, S., Rajendran, S., 2011b. Hydrogeochemistry of the Paravanar River Sub-Basin, Cuddalore District, Tamilnadu, India. E-Journal of Chemistry,8(2), 835-845, doi:10.1155/2011/107261.

47. Shankar, K., Aravindan, S., Rajendran, S., 2011c. Hydrochemical profile for assessing the groundwater quality of Paravanar River Sub-Basin, Cuddalore district, Tamil Nadu, India, Current World Environment, 6(1), 45-52.

48. Shankar.K, Aravindan.S and Rajendran.S, 2011d. Assessment of Ground Water Quality in Paravanar River Sub-Basin, Cuddalore district, Tamil Nadu, India. Advances in Applied Science Research, 2 (5):92-103.

49. Shahid, M., Dumat, C., Khalid, S., Rabbani, F., Farooq, A. B. U., Amjad, M., Niazi, N. K. (2019). Foliar uptake of arsenic nanoparticles by spinach: an assessment of physiological and human health risk implications. Environmental Science and Pollution Research,26(20), 20121-20131.

50. Siirila, E. R., Navarre-Sitchler, A. K., Maxwell, R. M., \& McCray, J. E. (2012). A quantitative methodology to assess the risks to human health from CO2 leakage into groundwater. Advances in Water Resources, 36, 146-164 
51. Stefania, G. A., Rotiroti, M., Buerge, I. J., Zanotti, C., Nava, V., Leoni, B., Bonomi, T. (2019). Identification of groundwater pollution sources in a landfill site using artificial sweeteners, multivariate analysis and transport modeling. Waste Management, 95, 116-128.

52. Szabolcs I, Darab C (1964) The influence of irrigation water of high sodium carbonate content on soils. In: Szabolics I (ed) Proceedings of the 8th international congress soil science sodics soils, Research Institute for Soil Science and Agricultural Chemistry of the Hungarian Academy of Sciences, ISSS Trans II, pp 802-812

53. Tabassum, R. A., Shahid, M., Dumat, C., Niazi, N. K., Khalid, S., Shah, N. S., Khalid, S. (2019). Health risk assessment of drinking arsenic-containing groundwater in Hasilpur, Pakistan: effect of sampling area, depth, and source. Environmental Science and Pollution Research, 26(20), 2001820029.

54. U.S. EPA. 2006. USEPA Region III Risk-based Concentration Table: Technical Background Information. United States Environmental Protection Agency, Washington, DC U.S. EPA. 2014. Human Health Evaluation Manual, Supplemental Guidance: Update of Standard Default Exposure Factors-OSWER Directive 9200.1-120. PP.6

55. Wongsasuluk, P., Chotpantarat, S., Siriwong, W., \& Robson, M. (2014). Heavy metal contamination and human health risk assessment in drinking water from shallow groundwater wells in an agricultural area in Ubon Ratchathani province, Thailand. Environmental geochemistry and health, 36(1), 169-182.
56. Wu, J., Li, P., Wang, D., Ren, X., \& Wei, M. (2019). Statistical and multivariate statistical techniques to trace the sources and affecting factors of groundwater pollution in a rapidly growing city on the Chinese Loess Plateau. Human and Ecological Risk Assessment: An International Journal, $1-19$.

57. WHO. 2013. World Health Statistics. World Health Organization, Geneva.

58. Yadav, K. K., Kumar, V., Gupta, N., Kumar, S., Rezania, S., \& Singh, N. (2019). Human health risk assessment: study of a population exposed to fluoride through groundwater of Agra city, India. Regulatory Toxicology and Pharmacology, 106, 68-80.

59. Zakir, H. M., Akter, A., Rahman, A., Sharmin, S., \& Arafat, M. Y. (2018). Groundwater quality evaluation for irrigation and drinking utilities collected from Sadar Upazila of Jamalpur District, Bangladesh. Asian Journal of Applied Chemistry Research, 1-13.

60. Zhang, Y., Li, S., Fang, Q., Duan, Y., Ou, P., Wang, L., \& Chen, Z. (2019a). Implementation of long-term assessment of human health risk for metal contaminated groundwater: A coupled chemical mass balance and hydrodynamics model. Ecotoxicology and environmental safety, 180, 95105.

61. Zhang, Y., Xu, B., Guo, Z., Han, J., Li, H., Jin, L., Xiong, Y. (2019b). Human health risk assessment of groundwater arsenic contamination in Jinghui irrigation district, China. Journal of environmental management, 237, 163-169. 